\title{
An Investigation Into the Short-Term Effects of Biochar on Nitrate Leaching From Artificial Columns of Sand
}

\author{
Daniel Sombo ${ }^{1}$ \\ ${ }^{1}$ Department of Agriculture, Health and Environment, Institute of Natural Resources, University of Greenwich, \\ UK
}

Correspondence: Daniel Sombo, Department of Agriculture, Health and Environment, Institute of Natural Resources, University of Greenwich, UK. E-mail: danielsombo@gmail.com

Received: January 24, 2018

Accepted: March 8, $2018 \quad$ Online Published: April 15, 2018

doi:10.5539/jas.v10n5p24

URL: https://doi.org/10.5539/jas.v10n5p24

\begin{abstract}
Leaching of $\mathrm{NO}_{3}$ has been shown to be a major problem in coarse-textured sandy soils. It has been suggested that biochar application to sandy soils could reduce leaching of $\mathrm{NO}_{3}$. However, how biochar could be used to provide short-term $\mathrm{NO}_{3}$ leaching reduction in sandy soils has received little research attention. Therefore, the aim of this study was to determine if and how biochar could be used to reduce $\mathrm{NO}_{3}$ leaching from artificial columns of sand (sandy soil). To achieve this, a simple assay was developed in a controlled temperature room to assess the short-term impacts of biochar on $\mathrm{NO}_{3}$ leaching from a column containing sand. The capacity to pick-up variations in $\mathrm{NO}_{3}$ leaching pattern from the sand columns based on the concentrations of the $\mathrm{NO}_{3}$ solutions used to perfuse the sand columns, as well as, the rate at which these solutions were perfused through the sand columns using this approach was initially established. A pulse chase experiment showed that the $\mathrm{NO}_{3}$ was very mobile, and once the supply was removed, the column of sand rapidly lost the $\mathrm{NO}_{3}$. The exception appears to the inclusion of biochar where this process is slowed down, but eventually the sand column lost all the $\mathrm{NO}_{3}$. When oak biochar produced through high temperature pyrolysis $\left(500-600{ }^{\circ} \mathrm{C}\right)$ by a commercial producer (Humko, d.o.o., Bled Sheenjek, Slovenija) was applied to the sand columns at a rate of $10 \%(\mathrm{w} / \mathrm{w})$, the pattern of $\mathrm{NO}_{3}$ leaching was modified. Biochar appeared to delay $\mathrm{NO}_{3}$ leaching from the sand. The extent of this delay, and how it may influence $\mathrm{NO}_{3}$ availability in the soil for plant uptake requires further research.
\end{abstract}

Keywords: biochar, leaching, nitrate, adsorption, asymptote

\section{Introduction}

Nitrogen is one of the most essential elements that supports all life in the biosphere (Bernhard, 2010). It is an essential constituent of most biological molecules in plants and animals, including RNA and DNA, ATP, chlorophyll, proteins, enzymes and hormones (Vitousek et al., 2002; Rachmilevitch, 2004; Pidwirny, 2006; Bernhard, 2010). In the atmosphere, it is the most abundant gas (78\%), but in most soils, it is the most limiting element for plant growth (Bernhard, 2010). This is because, plants cannot directly utilize nitrogen $\left(\mathrm{N}_{2}\right)$ in its gaseous form (Pidwirny, 2006). Most of the nitrogen plants take up is in the form of nitrate $\left(\mathrm{NO}_{3}\right.$ ) (Pidwirny, 2006). As such, applications of nitrogen fertilizers are used to supplement the plants' nitrogen requirement in the soil (Cameron et al., 2013).

However, high fertilizer application rates have resulted in the ions of $\mathrm{NO}_{3}$ leaching from agricultural soils in many cases (Cameron et al., 2013). This leaching process removes the $\mathrm{NO}_{3}$ not taken up by plants or chemically associated with soil particles beyond the reach of the plants roots resulting in a reduction in soil fertility, crop growth and yield (Laird et al., 2010). The leached $\mathrm{NO}_{3}$ also ends up polluting underground and surface waters (Kundu et al., 2009). Pollution of drinking water by $\mathrm{NO}_{3}$ has been reported as a major threat to human health (Fewtrell, 2004; Grizzetti et al., 2011). $\mathrm{NO}_{3}$ pollution of drinking water is the main cause of methaemoglobinaemia in children under the age of one (Grizzetti et al., 2011). It has also been suggested that high concentrations of $\mathrm{NO}_{3}$ in drinking water can cause heart disease and cancer (Fewtrell, 2004; Grizzetti et al., 2011). According to the World Health Organisation (2007), about 10 million people in Europe are exposed to water with $\mathrm{NO}_{3}$ concentrations above the recommend threshold $\left(50 \mathrm{mg} \mathrm{L}^{-1} \mathrm{NO}_{3}\right)$. Also, $\mathrm{NO}_{3}$ pollution of surface waters such as lakes and rivers leads to eutrophication, which usually causes elevated algae bloom, and in 
addition, leads to the death of aquatic organisms, loss of biodiversity and ecosystem services (Smith \& Schindler, 2009).

Consequently, the World Health Organization, WHO (2006) and the European Commission, EC (1998) has set a threshold of $50 \mathrm{mg} \mathrm{L} \mathrm{NO}_{3}$ concentration in drinking water to control the release of $\mathrm{NO}_{3}$ from all sources including agriculture. As a result, in England, the use of nitrogen fertilizers has been restricted in all areas which are classified as $\mathrm{NO}_{3}$ vulnerable (about $55 \%$ of the total agricultural land) (Scholefield, 2003). Likewise, in the USA, the Environmental Protection Agency has set the critical $\mathrm{NO}_{3}$ concentrations in drinking water to $10 \mathrm{mg}$ $\mathrm{L}^{-1}$ (EPA, 2009).

Thus, reducing $\mathrm{NO}_{3}$ leaching from agricultural lands is not only an environmental necessity but now regulatory. Hence, the need to find interventions to reduce $\mathrm{NO}_{3}$ leaching is inevitable. Biochar application has been suggested as an option to reduce leaching of $\mathrm{NO}_{3}$ in the soil (Yao et al., 2012; Sika \& Hardie, 2014; Zhao et al., 2014). Biochar is a carbon rich material produced through the thermal decomposition of organic materials in an oxygen deficient environment (Lehmann \& Joseph, 2009).

Lehmann et al. (2003) and Steiner et al. (2008) suggested that biochar could offer a long-term positive effect on soil nutrient retention and thereby restricting nutrient leaching in the soil. For example, in the Amazon, one distinctive feature of the biochar amended soils (Terra preta) compared to the surrounding soils (Oxisols) was the long-term nutrient retention (Lehmann et al., 2003). This is because, when biochar is applied to soil, it increases the soil's cation exchange capacity (CEC), improves its physical properties and ultimately nutrient retention (Laird et al., 2010; Major et al., 2010). Ding et al. (2010) explained that biochars with high density of ionic sites on their surfaces enhanced the soils' ability to adsorb $\mathrm{NO}_{3}$ and hence restrict $\mathrm{NO}_{3}$ leaching from the soil. This enhanced ionic surface characteristic of biochar when applied to soil improves its adsorption capacity and thus promotes the retention of more nutrients in the soil (Kameyama et al., 2012). Spokas et al. (2012) showed that high porosity and surface area of biochar increases the sorption sites on its surface which enables it to adsorb and retain nutrients particularly when incorporated into the soil. Furthermore, biochar is suggested to improve the ability of soil to hold water (Dempster et al., 2012) and this may indirectly decrease the vertical washing down of $\mathrm{NO}_{3}$ in the soil (Karhu et al., 2011). These characteristics have attracted researchers' attention to finding out how biochar could be used to reduce $\mathrm{NO}_{3}$ leaching (Dempster et al., 2012; Kameyama et al., 2012; Yao et al., 2012; Sika \& Hardie, 2014; Zhao et al., 2014).

However, much is not known about how biochar reduces $\mathrm{NO}_{3}$ leaching in coarse-texture soils. Moreover, little is known about the capacity of biochar to provide short-term reduction in $\mathrm{NO}_{3}$ leaching losses. Therefore, more research is required to investigate the ability of biochar to reduce $\mathrm{NO}_{3}$ leaching in coarse-textured soils such as sandy soils and also, the capacity of biochar to provide short-term reduction in $\mathrm{NO}_{3}$ leaching losses. This is also important, as the benefit of biochars is likely to be greatest in coarse-textured sandy soils (Jeffery et al., 2011).

The aims of this study are therefore intended to answer the following research questions: 1) can biochar be used to reduce $\mathrm{NO}_{3}$ leaching in coarse-textured sandy soils? and 2) can biochar offer short-term $\mathrm{NO}_{3}$ leaching reduction in coarse-textured sandy soils when $\mathrm{N}$ fertilizers are applied during high rainfall seasons such as in the winter? The objective of this study is to contribute to the expansion of our knowledge and understanding on how biochar may offer short-term $\mathrm{NO}_{3}$ leaching reduction in coarse-textured sandy soils.

\section{Methodology}

\subsection{Designing and Validating the Experimental Approach}

The intension of this study was to develop a simple assay to assess the short-term impacts of biochar on $\mathrm{NO}_{3}$ leaching from a soil column. By using sand in the assay, the expectation was that soluble $\mathrm{NO}_{3}$ would show little retention within the sand column and as such, $\mathrm{NO}_{3}$ leaching would be most easily detected in sand filled columns In order to achieve this, several pre-experiments were performed to validate the approach to be used. As part of this, three sand columns were constructed from PVC pipes (utilizing domestic waste water piping) measuring 66 $\mathrm{cm}$ in length and $4 \mathrm{~cm}$ in diameter (internal diameter) (Figure 1). Sand was used to fill the columns. Sand was used for this studies because, it is known that leaching of $\mathrm{NO}_{3}$ is generally high in sandy soils (Sohi et al., 2009; Jeffery et al., 2011; Cameron et al., 2013), and hence, it is important to assess the approach by which leaching from sandy soils could be reduced. The sand used was a horticultural grade silver sand (with particle size of about $0.1 \mathrm{~mm}$ to $1 \mathrm{~mm}$ ) commercially available at William Sinclair horticulture Ltd, Lincoln, UK.

Silver sand was chosen because, it is chemically inert and as such, unlikely to bind $\mathrm{NO}_{3}$. Also, it has been suggested that the ability of biochar to reduce soil nutrient leaching from soils is likely to be greatest in coarse-textured sandy soils (Jeffery et al., 2011). They attributed this to the fact that biochar enhanced water 
holding capacity of coarse-textured sandy soils more significantly than fine-textured soil. Moreover, sandy soils have lower cation exchange capacity due to their lower organic matter content than fine-textured soils, and as such, biochar may significantly enhance the cation exchange capacity when they are incorporated into sandy soils (Sohi et al., 2009).

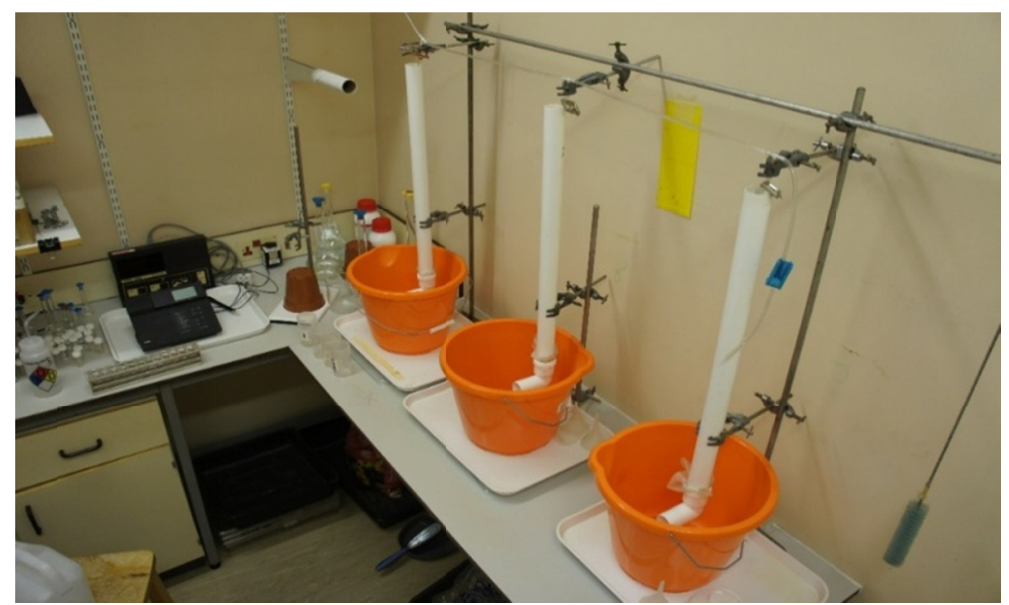

Figure 1. Control temperature room experimental assay for the study of nitrate leaching from artificial media columns (Temperature: $25 \pm 0.5{ }^{\circ} \mathrm{C}$, Humidity, $50 \pm 0.1 \%$ )

The three sand columns shown (Figure 1) were used to provide three replicates per experiment. Each of the columns was gravity fed with perfusing solutions draining through the columns under the influence of gravity. As such, each column was kept vertical in all the experiments. The flow of the purfusing solution was regulated by a flow restrictor fixed at the base of the leachate reservoir (Figure 2). The outlets from the tube into all the sand columns were also fixed with flow regulators to adjust flow rate (control of the purfusing solution supplied to the sand columns per unit time) (Figure 1).

The bottoms of all the sand columns were sealed with nylon mesh (about $<0.01 \mathrm{~mm}$ ). A ten litre plastic leachate reservoir was used to provide the purfusing solution (Figure 2). A polythene tube with internal diameter of 0.6 $\mathrm{cm}$ connected to this leachate reservoir was used to supply the purfusing solutions to the sand columns. The tube was mounted on retort stands situated at each outlet of the tube (Figure 2). 


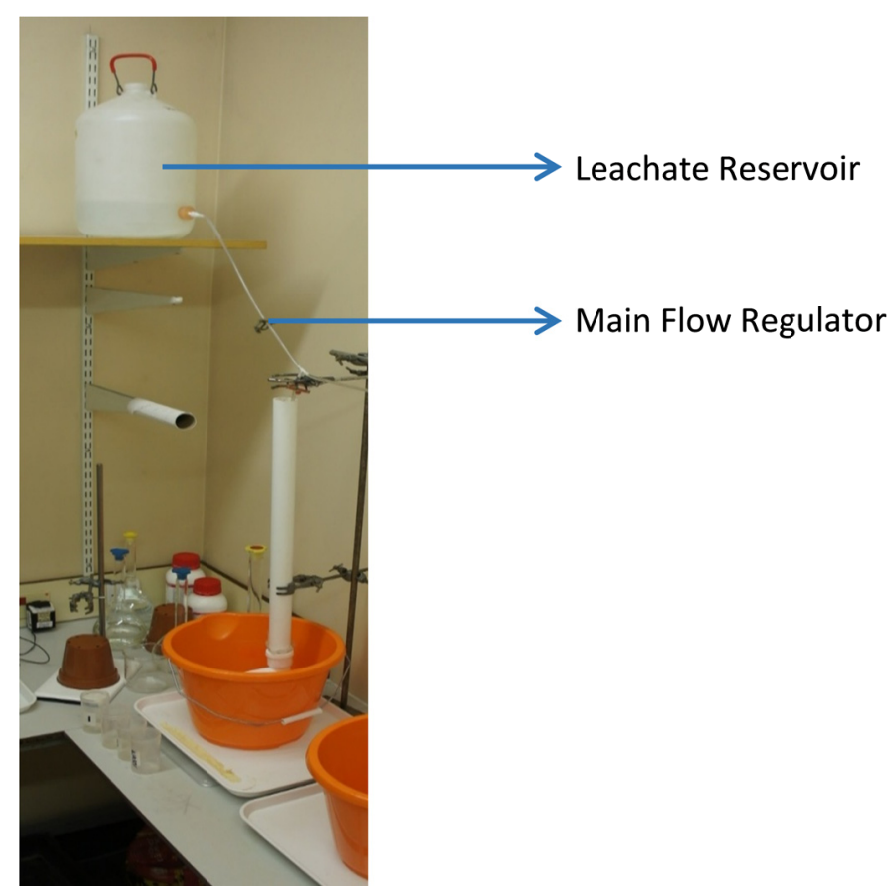

Figure 2. Control room experimental assay for the study of nitrate leaching from artificial media columns (Temperature: $25 \pm 0.5^{\circ} \mathrm{C}$, Humidity, $50 \pm 0.1 \%$ )

\subsection{Preparation of Standard $\mathrm{NO}_{3}$ Solutions and Calibration of the Ion Selective Electrode (ISE)}

Standard $\mathrm{NO}_{3}$ stock solution of $16.13 \mathrm{mmol} \mathrm{L}$ (1000 ppm) was prepared using ammonium nitrate $\left(\mathrm{NH}_{4} \mathrm{NO}_{3}\right)$ (Sigma-Aldrich Company Ltd., Gillingham, and Dorset, UK). Five standard nitrate solutions were then prepared from this stock solution by dilution. These standard solutions were $0.18 \mathrm{mmol} \mathrm{L}^{-1}(11 \mathrm{ppm}), 0.4 \mathrm{mmol} \mathrm{L}^{-1}(24.8$ ppm), $1.1 \mathrm{mmol} \mathrm{L}^{-1}(68 \mathrm{ppm}), 1.9 \mathrm{mmol} \mathrm{L}^{-1}(118 \mathrm{ppm})$, and $4.4 \mathrm{mmol} \mathrm{L}^{-1}(273 \mathrm{ppm})$. These concentrations were chosen to encompass the average $\mathrm{NO}_{3}$ concentration in agriculture sandy loam soil solutions (about $1.3 \mathrm{mmol} \mathrm{L}^{-1}$, $80 \mathrm{ppm}$, to about $2.7 \mathrm{mmol} \mathrm{L}^{-1}, 168 \mathrm{ppm}$ ) (Jamtgard et al., 2010). Also, Ionic Strength Adjustment Buffer (ISAB) was prepared from ammonium monohydrate from Sigma-Aldrich Company Ltd. (2014). This solution was used to regulate ionic strength of all standard and sample $\mathrm{NO}_{3}$ solutions. Thus, the effectiveness of the ISE in detecting $\mathrm{NO}_{3}$ ions in solutions could be interfered by the presence of other ions (Tani \& Umezawa, 2005). As such, $1 \mathrm{ml}$ of the ISAB was added to every $50 \mathrm{ml}$ of both the standard and the sample solutions in all the experiments.

The five standard $\mathrm{NO}_{3}$ solutions were used to calibrate the Ion specific electrode (ISE). The ISE is a mono electrode which is designed specifically to detect only $\mathrm{NO}_{3}$ ions in solutions (Tani \& Umezawa, 2005). Thus, through it selective membrane, it is able to detect $\mathrm{NO}_{3}$ ions in solutions. As a result, it was assumed that ISE could detect $\mathrm{NO}_{3}$ ions in leachates from the sand columns. This ISE was connected to a standard meter set to read electrode $\mathrm{mV}$. The initial concentrations used were $\log _{10}$ and plotted against $\mathrm{mV}$ readings to obtain a calibration line (Figure 2). Calibration of the ISE was repeated at the beginning and end of every experiment to ensure consistency and reproducibility. Measurements of the standard solutions were made during the experiments to ensure measurement consistency. 


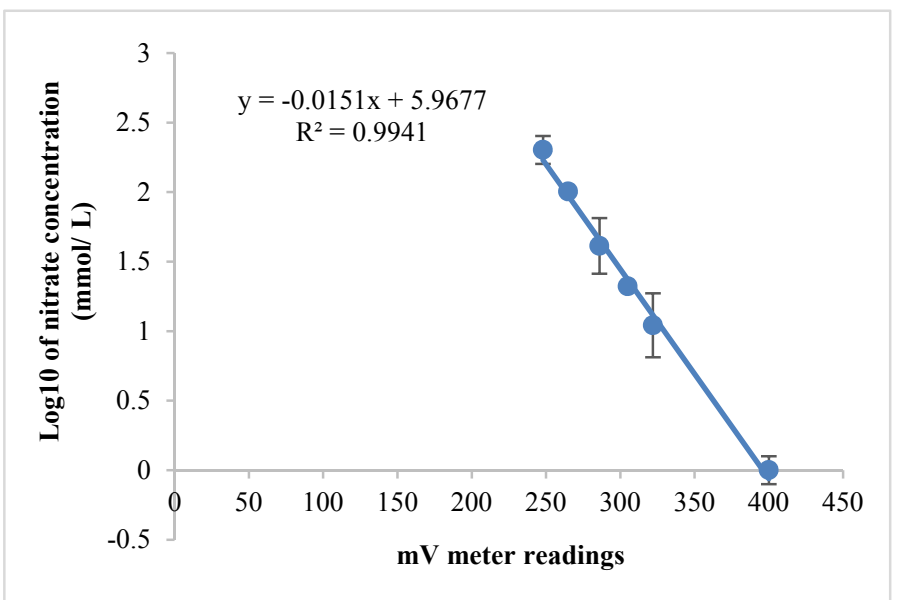

Figure 3. Calibration line for five standard nitrate solutions $\left(0.18 \mathrm{mmol} \mathrm{L}^{-1}, 0.4 \mathrm{mmol} \mathrm{L}^{-1}, 1.1 \mathrm{mmol} \mathrm{L}^{-1}, 1.9\right.$ moles $\mathrm{L}^{-1}$, and $4.4 \mathrm{mmol} \mathrm{L}^{-1}$, the fitted linear model was carried out using Microsoft Excel)

\subsection{Biochar Evaluation}

The biochar used in this study was produced through high temperature pyrolysis $\left(550-600{ }^{\circ} \mathrm{C}\right)$ of oak, by a commercial producer (Humko, d.o.o., Bled Sebenje, Slovenija). This biochar is highly absorbent due to its high porosity. It was purposely chosen for this experiment because of its high adsorption capacity. Yao et al. (2012) reported that only high temperature pyrolysis biochar with high adsorption capacity have effect on $\mathrm{NO}_{3}$ adsorption. The particle size of the biochar (about between $2.8 \mathrm{~mm}$ and $0.09 \mathrm{~mm}$ ) was determined using Endocots Sieve system with Endecot Test Sieve Shaker at an amplitude of 1.6 revolution per minute.

\subsection{Nitrate Leaching in Pulse-Chase Experiments}

Two experiments were carried out. The aim of the the first experiment was to determine how quickly $\mathrm{NO}_{3}$ applied to sand only columns will be leached out after perfusing deionised water through the sand columns. This was particularly important in simulating possible fertilizer application on farms, where applied fertilizers could be leached by rains or irrigation. Through this experiment, the hypothesis that sand will have insignificant effect on $\mathrm{NO}_{3}$ retention in the sand columns was tested. In order to achieve this, $4.4 \mathrm{mmol} \mathrm{L}{ }^{-1}$ of $\mathrm{NO}_{3}$ solution was perfused through the sand columns containing $641 \mathrm{~g}$ sand at a rate of $7.7 \mathrm{ml} \mathrm{min}^{-1}$. The perfusing of the sand columns with the $4.4 \mathrm{mmol} \mathrm{L}^{-1}$ of $\mathrm{NO}_{3}$ solution was switched to deionised water after constant maximum concentration (asymptote) in the leachate was obtained. These columns were perfused with the deionised water until constant $\mathrm{NO}_{3}$ concentration in the leachates was obtained. It was assumed that at this lower but constant concentration, all the available leachable $\mathrm{NO}_{3}$ having been leached with the remainder being retained in the sand.

In the second experiment however, the aim was to determine if the use of biochar in the column will alter the pattern of $\mathrm{NO}_{3}$ leaching seen in the experiment with silver sand alone. This experiment was used to test the hypothesis that biochar can reduce the leaching of $\mathrm{NO}_{3}$ from soils. In this experiment, biochar was added to the sand columns at a rate of $10 \%(\mathrm{w} / \mathrm{w})(64 \mathrm{~g}$ of biochar in $641 \mathrm{~g}$ sand columns). The biochar was applied at a depth of $20 \mathrm{~cm}$ below the top of the sand in the columns. This depth chosen was based on the finding of Ding et al. (2010) that leaching of $\mathrm{NO}_{3}$ was significantly reduced when biochar was applied at a depth of $20 \mathrm{~cm}$. The sand-biochar columns were first saturated with deionised water.

Nitrate solution $\left(4.4 \mathrm{mmol} \mathrm{L}^{-1}\right)$ was perfused through the sand-biochar columns at a rate of $7.7 \mathrm{ml} \mathrm{min}{ }^{-1}$. The perfusing of the $\mathrm{NO}_{3}$ solution through the sand-biochar column was switched to deionised water after constant maximum concentration of $\mathrm{NO}_{3}$ was obtained in the leachates from these columns. These sand-biochar columns were perfused with the deionised water until a constant $\mathrm{NO}_{3}$ concentration was again obtained in the leachates.

\subsection{Statistical Analysis of Data}

Means and standard errors of the response variable (concentration of $\mathrm{NO}_{3}$ in leachates) for every treatment in all the experiments were computed using Microsoft Excel 2013. Also, the effects of the treatments on this response variable were analysed statistically using Statistical Package for Social Science (SPSS) (version 18.0). 


\section{Results}

\subsection{Effects of Biochar on $\mathrm{NO}_{3}$ Leaching From the Sand Columns in Pulse-Chase Experiments}

When $\mathrm{NO}_{3}$ solution $\left(4.4 \mathrm{mmol} \mathrm{L}^{-1}\right)$ was applied to the columns containing sand only at a rate of $7.7 \mathrm{ml} \mathrm{min}^{-1}$, the concentration of $\mathrm{NO}_{3}$ in the leachate rose rapidly $\left(0.10 \pm 0.01 \mathrm{mmol} \mathrm{L}^{-1} \mathrm{~min}^{-1}\right)$ to an asymptote of $2.20 \pm 0.03$ mmol L${ }^{-1}$ on the 25 minute (Figure 4 and Table 3). However, when $\mathrm{NO}_{3}$ solution $\left(4.4 \mathrm{mmol} \mathrm{L}^{-1}\right.$ ) was applied to the biochar amended sand columns at the same rate, the concentration of $\mathrm{NO}_{3}$ in the leachate increased gradually $\left(0.05 \pm 0.02 \mathrm{mmol} \mathrm{L}^{-1}\right.$ minute $\left.^{-1}\right)$ till an asymptote was reached $\left(1.87 \pm 0.02 \mathrm{mmol} \mathrm{L}^{-1}\right)$ on the 40 minute (Figure 4 and Table 3). After asymptotes were reached, the concentration of the $\mathrm{NO}_{3}$ in the leachates from the sand only columns declined rapidly $\left(0.04 \mathrm{mmol} \mathrm{L}^{-1}\right.$ minute ${ }^{-1}$ ) (Figure 4 and Table 3 ) from about $2.20 \pm 0.03 \mathrm{mmol} \mathrm{L}^{-1}$ on the 25 minute to about $0.04 \pm 0.02 \mathrm{mmol} \mathrm{L}^{-1}$ on the 60 minute when these $\mathrm{NO}_{3}$ saturated sand columns were perfused with deionised water at a rate of $7.7 \mathrm{ml} \mathrm{min}{ }^{-1}$. However, in the leachates from the biochar amended sand columns, the concentration of the $\mathrm{NO}_{3}$ declined gradually $\left(0.003 \pm 0.01 \mathrm{mmol} \mathrm{L}^{-1}\right.$ minute ${ }^{-1}$ ) (Figure 4 and Table 3 ) from about $1.87 \pm 0.001 \mathrm{mmol} \mathrm{L}^{-1}$ around 5 minutes to about $0.19 \pm 0.01 \mathrm{mmol} \mathrm{L}^{-1}$ after 60 minutes when these $\mathrm{NO}_{3}$ saturated biochar amended columns were also perfused with deionised water at the same rate.

Moreover, when the $4.4 \mathrm{mmol} \mathrm{L}^{-1}$ of $\mathrm{NO}_{3}$ solution was perfused through the columns at a rate of $7.7 \mathrm{ml} \mathrm{min}^{-1}$, the rise in $\mathrm{NO}_{3}$ concentration in the leachates from the sand only columns began earlier than that in the leachates from the biochar amended columns (Figure 4 and Table 1).
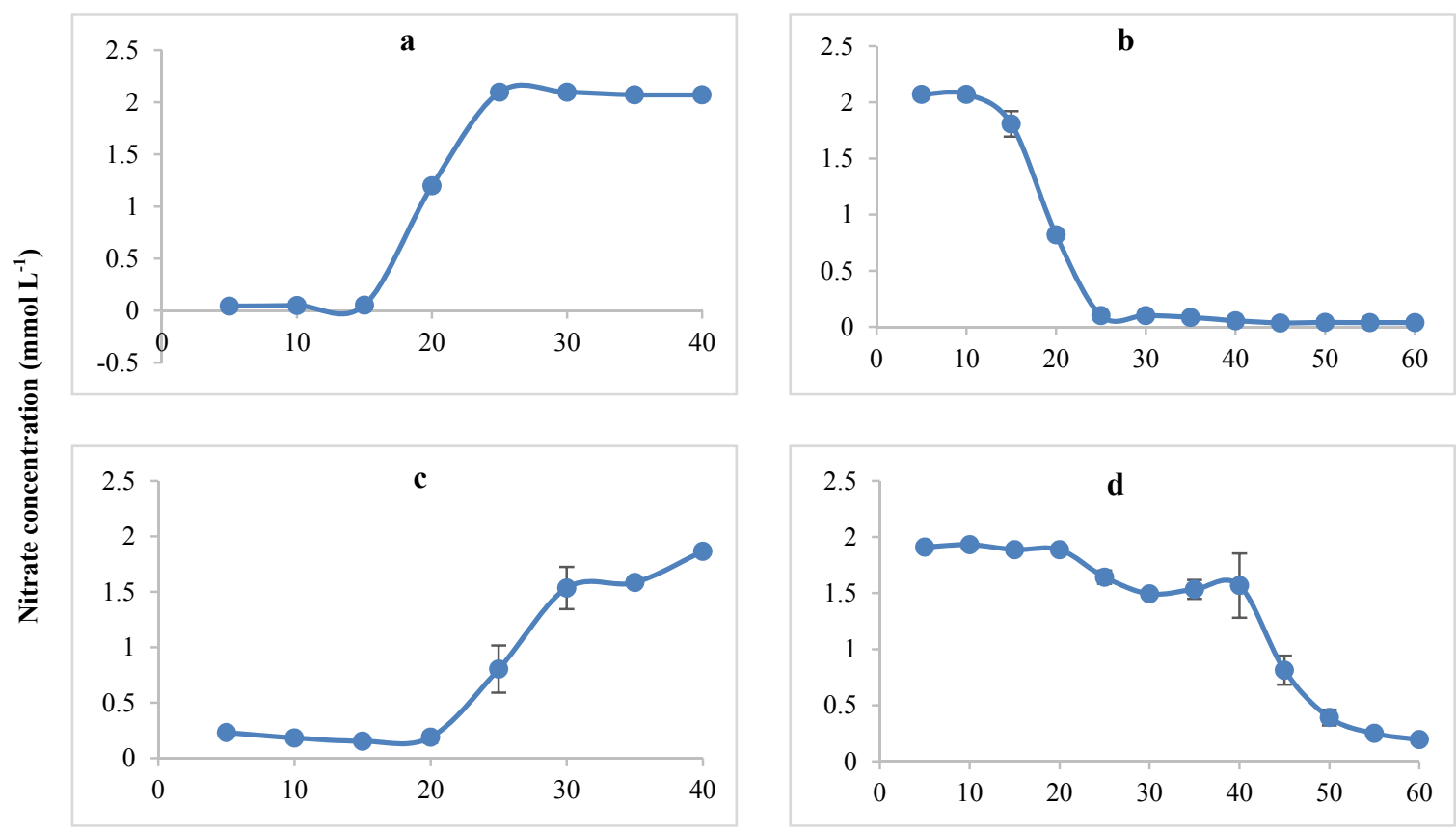

Time (minutes)

Figure 4. Temporal changes of nitrate concentration in leachates of biochar amended columns and sand only columns

Note. (a) and (b) shows changes in nitrate concentration in the leachates when $4.4 \mathrm{mmol} \mathrm{L}^{-1}$ of nitrate solution was perfused through columns of sand only and biochar amended sand columns in pulse respectively, (c) and (d) shows temporal changes in nitrate concentration in the leachates when columns (a) and (b) were subsequently leached with deionised water (Experimental variables: Sand: $641 \mathrm{~g}$, perfusion rate: $7.7 \mathrm{ml} \mathrm{min}^{-1}$ ). 
Table 1. Effects of biochar on the asymptotes and slopes of $\mathrm{NO}_{3}$ concentration in leachates after the high $\mathrm{NO}_{3}$ concentration solution $\left(4.4 \mathrm{mmol} \mathrm{L} \mathrm{L}^{-1}\right)$ was perfused through biochar amended columns and sand only columns using pulse-chase method at a rate of $7.7 \mathrm{ml} \mathrm{min}^{-1}$

\begin{tabular}{lll}
\hline \multirow{2}{*}{ Experimental variables } & \multicolumn{2}{c}{ Time } \\
\cline { 2 - 3 } & $\begin{array}{l}\text { Time until an increase in nitrate } \\
\text { concentration was detected (minutes) }\end{array}$ & $\begin{array}{l}\text { Time required to attain a constant } \\
\text { value (minutes) }\end{array}$ \\
\hline Sand only columns & $10 \pm 0.57$ & $25 \pm 0.001$ \\
Biochar amended columns & $15 \pm 0.85$ & $40 \pm 1.06$ \\
\hline
\end{tabular}

Table 2. The effect of biochar on the half-life of nitrate in the sand columns

\begin{tabular}{llll}
\hline Experimental variable & $\begin{array}{l}\text { Nitrate concentration } \\
\text { at asymptotes }\left(\mathrm{mmol} \mathrm{L}^{-1}\right)\end{array}$ & $\begin{array}{l}\text { Nitrate concentration } \\
\text { at half-life }\left(\mathrm{mmol} \mathrm{L}^{-1}\right)\end{array}$ & Half-life (minutes) \\
\hline Sand only columns & $2.20 \pm 0.02$ & $1.10 \pm 0.03$ & $18 \pm 0.001$ \\
Biochar amended columns & $1.87 \pm 0.07$ & $0.94 \pm 0.05$ & $40 \pm 0.78$ \\
\hline
\end{tabular}

Note. Half-life $=$ time taken for concentration of nitrate to decline by $50 \%$ of the maximum (data derived from Figure 4).

Furthermore, the half-life of $\mathrm{NO}_{3}$ in the biochar amended columns appeared to be higher than that in the sand only columns (Table 2). In the sand only columns, it took about 18 minutes for the nitrate to decline by $50 \%$ of the maximum, whereas, in the biochar amended columns, it took about 40 minutes for the $\mathrm{NO}_{3}$ to decline by $50 \%$ of the maximum, when the perfusion of the columns was switched from $\mathrm{NO}_{3}$ concentration to deionised water.

Table 3. Effects of biochar on the asymptotes and slopes of $\mathrm{NO}_{3}$ concentration in leachates after the high $\mathrm{NO}_{3}$ concentration solution $\left(4.4 \mathrm{mmol} \mathrm{L}^{-1}\right)$ was perfused through columns using pulse-chase method

\begin{tabular}{|c|c|c|c|}
\hline \multirow{2}{*}{ Experimental variables } & \multicolumn{2}{|c|}{ Pulse application of $4.4 \mathrm{mmol} \mathrm{L}^{-1} \mathrm{NO}_{3}$ solution } & \multirow{2}{*}{$\begin{array}{l}\begin{array}{l}\text { Perfusion of } \mathrm{NO}_{3} \text { saturated columns with } \\
\text { deionised water at a rate of } 7.7 \mathrm{ml} \mathrm{min}^{-1}\end{array} \\
\left.\begin{array}{l}\text { Slope } \\
(\mathrm{mmol} \mathrm{L}\end{array} \text { minute }^{-1}\right)\end{array}$} \\
\hline & $\begin{array}{l}\text { Asymptote (mean } \pm \text { standard error) } \\
\left(\mathrm{mmol} \mathrm{L}^{-1}\right)\end{array}$ & $\begin{array}{l}\text { Slope } \\
\left(\mathrm{mmol} \mathrm{L}^{-1} \text { minute }^{-1}\right)\end{array}$ & \\
\hline Sand only columns & $2.20 \pm 0.03$ & $0.10 \pm 0.01$ & $0.04 \pm 0.03$ \\
\hline Biochar amended columns & $1.87 \pm 0.02$ & $0.05 \pm 0.02$ & $0.003 \pm 0.01$ \\
\hline p-values & $<0.001$ & 0.016 & 0.003 \\
\hline
\end{tabular}

\section{Discussion}

\subsection{Effects of Biochar on $\mathrm{NO}_{3}$ Leaching}

These experiments were carried out to test the hypothesis that application of biochar to the sand in the columns will reduce leaching of $\mathrm{NO}_{3}$ from the sand columns. This hypothesis was confirmed, as the concentration of $\mathrm{NO}_{3}$ in the leachates from the biochar amended soil columns was relatively lower than that in the sand only columns. This is apparent in the relatively higher peak concentration of $\mathrm{NO}_{3}$ in the leachates from the sand only columns than that in the biochar amended sand columns (Figure 4 and Table 3). It is also apparent in the relatively higher half-life of $\mathrm{NO}_{3}$ in the biochar amended sand columns than in the sand only columns (Table 2). The calculation used to measure the half-life of $\mathrm{NO}_{3}$ in the sand columns provided a simple way to quantify $\mathrm{NO}_{3}$ retention over time (the higher the half-life the higher the retention). This could be attributed to the relatively gradual increase in $\mathrm{NO}_{3}$ concentration in the leachates from the biochar amended columns than that in the sand only columns (Figure 4 and Table 1).

A possible explanation for this is that the biochar applied to the sand columns adsorbs a proportion of the $\mathrm{NO}_{3}$ solution perfused through the biochar amended sand columns and as such, reduced the concentration of the $\mathrm{NO}_{3}$ in the sand solutions in these columns. Dempster et al. (2012) tested the effectiveness of Eucalyptus marginata biochar in reducing $\mathrm{NO}_{3}$ leaching in sandy soils and found that $\mathrm{NO}_{3}$ leaching was significantly reduced after the application of this biochar. They explained that the reduction in the $\mathrm{NO}_{3}$ leaching was due to soil $\mathrm{NO}_{3}$ retention induced by the higher adsorption of the $\mathrm{NO}_{3}$ by the Eucalyptus marginata biochar. Similarly, in an experiment to determine the influence of pine wood biochar on $\mathrm{NO}_{3}$ leaching using laboratory sand columns, it was found that 
when the pine wood biochar was applied to the columns at a rate of $0.5,2.5$ and $10 \% \mathrm{w} / \mathrm{w}$, leaching of the $\mathrm{NO}_{3}$

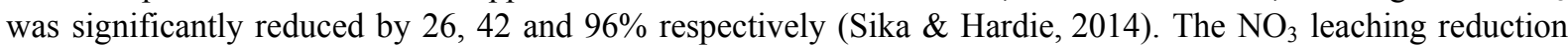
was attributed to the enhanced cation exchange capacity and water holding potential of these amended soils (Dempster et al., 2012; Sika \& Hardie, 2014). As such, the reduced leaching of $\mathrm{NO}_{3}$ from the biochar amended sand columns may be because, the cation exchange capacity of the sand in these columns was enhanced.

Also, in the current experiment, the leaching of $\mathrm{NO}_{3}$ was relatively gradual from the $\mathrm{NO}_{3}$ saturated biochar amended sand columns than the $\mathrm{NO}_{3}$ saturated sand only columns after deionised water was perfused through them. This relatively high leaching rate of $\mathrm{NO}_{3}$ in the sand only columns could be associated with the fact that sandy soils are coarse in texture and as such, water percolates through them more rapidly (T. P. Gaines \& S. T. Gaines, 1994; Silva et al., 2005; Cameron et al., 2013). Cameron et al. (2013) and Silva et al. (2005) attributed this to the low water holding capacity of the coarse-textured sandy soils. As stated earlier in the previous sections, sandy soils have low cation exchange capacity and this could also account for the high leaching rate in the sand only columns. Thus, in the sand columns, density of cations were perhaps low and hence, the sand particle probably did not have much electrostatic attraction on the negatively charged $\mathrm{NO}_{3}$ ions. Therefore, the anions $\left(\mathrm{NO}_{3}\right.$ ions) were easily leached out from the sand columns. This is in line with the assertion of Akosman and Ozdemir (2010) that high $\mathrm{NO}_{3}$ leaching in sandy soils is attributed to the inherently low cation exchange capacity of these soils.

On the hand, the reduced $\mathrm{NO}_{3}$ leaching in the biochar amended sand columns may probably be because, the biochar adsorbed some of the $\mathrm{NO}_{3}$. This can be attributed to the fact that the biochar used in this experiment was produced at a high temperature $\left(550-600{ }^{\circ} \mathrm{C}\right)$ and hence, it had a high adsorption capacity. Several studies have suggested that significant $\mathrm{NO}_{3}$ adsorption can be attained by using biochar produced at a relatively high temperature (about $600{ }^{\circ} \mathrm{C}$ ) (Ding et al., 2010; Knowles et al., 2011; Yao et al., 2012; Dempster et al., 2012; Kameyama et al., 2012; Sika \& Hardie 2014; Zhao et al., 2014). For instance, Yao et al. (2012) used Brazilian pepperwood and peanut hull biochars produced at a pyrolysis temperature of $600{ }^{\circ} \mathrm{C}$ to amend $\mathrm{NO}_{3}$ and $\mathrm{NH}_{4}$ leaching in soil columns and found that the amount of $\mathrm{NO}_{3}$ and $\mathrm{NH}_{4}$ leached from the soil columns were significantly reduced by $34 \%$ and $14 \%$ respectively when the pepperwood biochar was used.

Furthermore, since the decline in $\mathrm{NO}_{3}$ concentration in the leachates from the biochar amended sand columns was gradual (Figure 4 and Table 1), it can be suggested that the biochar perhaps did not immobilized the $\mathrm{NO}_{3}$ it adsorbed, but rather, it released the $\mathrm{NO}_{3}$ slowly into the soil solution as the deionised water was perfused through the columns. This result therefore suggests that the $\mathrm{NO}_{3}$ adsorbed by the biochar may be available for plant uptake as the biochar released some of the $\mathrm{NO}_{3}$ adsorbed. This is very important as some biochars may immobilise the $\mathrm{NO}_{3}$ they adsorb making it unavailable in the soil for plants (Sika \& Hardie, 2004). On the other hand, this biochar did not stop $\mathrm{NO}_{3}$ leaching, but rather, it delayed $\mathrm{NO}_{3}$ leaching from the columns. Furthermore, the troughs in $\mathrm{NO}_{3}$ leaching from the biochar amended sand columns may be ascribed to the fact that the biochar perhaps released the nutrient it adsorbed at different rates (Figure 4).

Alternatively, the reduction in $\mathrm{NO}_{3}$ leaching from the biochar amended sand columns could probably be related to the fact that the biochar enhanced water holding capacity in the sandy soil as it was observed that leachate volumes collected per unit time was relatively lower than that from the sand only columns (data not presented). Biochar has been suggested to improve the ability of soil to hold water (Dempster et al., 2012) and this may indirectly decrease the vertical leaching of $\mathrm{NO}_{3}$ by water (Karhu et al., 2011). Reduction of $\mathrm{NO}_{3}$ leaching in soils through water holding capacity improvement has also been reported by Sika and Hardie (2014).

Therefore, on the basis of these results, it could be suggested that biochar application to sandy soils may reduce $\mathrm{NO}_{3}$ leaching.

\section{Conclusion}

In this study, an artificial sand media was prepared to investigate $\mathrm{NO}_{3}$ leaching in a temperature controlled room. Clearly, it can be concluded that, this approach was able to pick-up differences in the pattern of $\mathrm{NO}_{3}$ leaching from a simple column of sand and the pattern changed in response to the presence and absence of biochar in the sand columns.

Biochar application at a rate of $10 \%(\mathrm{w} / \mathrm{w})$ to the sand columns modified the pattern of $\mathrm{NO}_{3}$ leaching from the sand columns. For instance, the half-life of $\mathrm{NO}_{3}$ in the biochar amended columns was about $20 \%$ higher than that in the sand only columns. Thus, $\mathrm{NO}_{3}$ leaching was relatively lower in the biochar amended columns than that in the sand only columns. Therefore, biochar could have some delay in leaching of $\mathrm{NO}_{3}$ from sandy soils. How long this delay will be, and how this delay will affect $\mathrm{NO}_{3}$ availability in the soil for plant uptake needs further investigation. 


\section{Acknowledgements}

First and foremost, I would like to thank God for seeing me through my study. I would like to express my profound gratitude to my supervisor, Professor Christopher J. Atkinson, for his exceptional guidance, motivation and support throughout this work. I would also like to thank the Government of the United Kingdom through Commonwealth Scholarship Commission, for sponsoring my studies.

My sincere thanks also goes to Dr P.J.A. Burt (programme leader) and all the staff of Natural Resources Institute who contributed to the success of my study at the university. I would like to also thank Tomaz Cufer (Humko, Slovenia) for providing the biochar used in this study. Also, a big thank you to Natalie Morley for supplying the sand used in this study. I am also grateful to Dr Stephen Young for his guidance during my data analysis. I would also like to thank Hanna Scott for her support during this work.

Last but not the least, I am grateful to all others who contributed to the success of this work.

\section{References}

Akosman, C., \& Ozdemir, T. (2010). Adsorption dynamics and equilibrium studies of nitrate onto various soils. Fresenious Enviromental Bulletin, 19, 2246-2252.

Bernhard, A. (2010). The Nitrogen Cycle: Processes, Players, and Human Impact. Nature Education Knowledge, $3(10), 25$.

Cameron, K. C., Di, H. J., \& Moir, J. L. (2013). Nitrogen losses from the soil/plant system: A review. Annals of Applied Biology, 162, 145-173. https://doi.org/10.1111/aab.12014

Dempster, D. N., Jones, D. L., \& Murphy, D. M. (2012). Clay and biochar amendments decreased inorganic but not dissolved organic nitrogen leaching in soil. Soil Research, 50, 216-221. https://doi.org/10.1071/SR11316

Ding, Y., Liu, Y. X., Wu, W. X., Shi, D. Z., Yang, M., \& Zhong, Z. K. (2010). Evaluation of biochar effects on nitrogen retention and leaching in multi-layered soil columns. Water, Air, and Soil Pollution, 213, 47-55. https://doi.org/10.1007/s11270-010-0366-4

EPA (Environmental Protection Agency). (2009). Drinking Water Standards and Health Advisories. USEPA Office of Drinking Water, Washington.

Fewtrell, L. (2004). Drinking-water nitrate, methaemoglonaemia, and global burden of disease: A discussion. Environmental Health Perspectives, 112, 1371-1374. https://doi.org/10.1289/ehp.7216

Gaines, T. P., \& Gaines, S. T. (1994). Soil texture effect on nitrate leaching in soil percolates. Communications in Soil Science and Plant Analysis, 25, 2561-2570. https://doi.org/10.1080/00103629409369207

Grizzetti, B., Bouraoui, F., Billen, G., van Grinsven, H., Cardoso, A. C., Thieu, V., ... Johnes, P. (2011). Nitrogen as a threat to European water quality. The European Nitrogen Assessment: Sources, Effects and Policy Perspectives (pp. 379-404). https://doi.org/10.1017/CBO9780511976988.020

Jamtgard, S., Nasholm, T., \& Huss-Danell, K. (2010). Nitrogen compounds in soil solutions of agricultural land. Soil Biology and Biochemistry, 42, 2325-2330. https://doi.org/10.1016/j.soilbio.2010.09.011

Jeffery, S., Verheijen, F. G. A., Van Der Velde, M., \& Bastos, A. C. (2011). A quantitative review of the effects of biochar application to soils on crop productivity using meta-analysis. Agriculture, Ecosystems and Environment, 144, 175-187. https://doi.org/10.1016/j.agee.2011.08.015

Kameyama, K., Miyamoto, T., Shiono, T., \& Shinogi, Y. (2012). Influence of sugarcane bagasse-derived biochar application on nitrate leaching in calcaric dark red soil. Journal of Environmental Quality, 41, 1131-1137. https://doi.org/10.2134/jeq2010.0453

Karhu, K., Mattila, T., Bergström, I., \& Regina, K. (2011). Biochar addition to agricultural soil increased $\mathrm{CH}_{4}$ uptake and water holding capacity Results from a short-term pilot field study. Agriculture, Ecosystems and Environment, 140, 309-313. https://doi.org/10.1016/j.agee.2010.12.005

Knowles, O. A., Robinson, B. H., Contangelo, A., \& Clucas, L. (2011). Biochar for the mitigation of nitrate leaching from soil amended with biosolids. Science of the Total Environment, 409, 3206-3210. https://doi.org/10.1016/j.scitotenv.2011.05.011

Kundu, M. C., Mandal, B., \& Hazra, G. C. (2009). Nitrate and fluoride contamination in groundwater of an intensively managed agroecosystem: A functional relationship. Science of the Total Environment, 407, 2771-2782. https://doi.org/10.1016/j.scitotenv.2008.12.048 
Laird, D., Fleming, P., Wang, B., Horton, R., \& Karlen, D. (2010). Biochar impact on nutrient leaching from a Midwestern agricultural soil. Geoderma, 158, 436-442. https://doi.org/10.1016/j.geoderma.2010.05.012

Lehmann, J., \& Joseph, S. (2009). Biochar for environmental management: science and technology. Earthscan.

Lehmann, J., da Silva, J., Steiner, C., Nehls, T., Zech, W., \& Glaser, B. (2003). Nutrient availability and leaching in an archaeological anthrosol and a ferralsol of the central amazon basin: Fertilizer, manure and charcoal amendments. Plant and Soil, 249, 343-357. https://doi.org/10.1023/A:1022833116184

Major, J., Rondon, M., Molina, D., Riha, S. J., \& Lehmann, J. (2010). Maize yield and nutrition during 4 years after biochar application to a Colombian savanna oxisol. Plant and Soil, 333, 117-128. https://doi.org/10.1007/ s11104-010-0327-0

Pidwirny, M. (2006). The Nitrogen Cycle. Fundamentals of Physical Geography (2nd ed.). Retrieved June 28, 2014, from http:/www.physicalgeography.net/fundamentals/9s.html

Rachmilevitch, S., Cousins, A. B., \& Bloom, A. J. (2004). Nitrate assimilation in plant shoots depends on photorespiration. Proceedings of the National Academy of Sciences of the United States of America, 101, 11506-11510. https://doi.org/10.1073/pnas.0404388101

Scholefield, D. (2003). some impacts of crop quality on environment and biodiversity. Aspects of Applied Biology, 70, 53-61.

Sika, M. P., \& Hardie, A. G. (2014). Effect of pine wood biochar on ammonium nitrate leaching and availability in a South African sandy soil. European Journal of Soil Science, 65, 113-119. https://doi.org/10.1111/ejss.12082

Silva, R. G., Holub, S. M., Jorgensen, E. E., \& Ashanuzzaman, A. N. M. (2005). Indicators of nitrate leaching loss under different land use of clayey and sandy soils in southeastern Oklahoma. Agriculture, Ecosystems and Environment, 109, 346-359. https://doi.org/10.1016/j.agee.2004.12.018

Smith, V. H., \& Schindler, D. W. (2009). Eutrophication science: Where do we go from here? Trends in Ecology and Evolution, 24, 201-207. https://doi.org/10.1016/j.tree.2008.11.009

Sohi, S., Loez-Capel, S. E., Krull, E., \& Bol, R. (2009). Biochar's roles in soil and climate change: A review of research needs. Land and water science report 05/09, February (p. 64). CSIRO.

Spokas, K. A., Novak, J. M., \& Venterea, R. T. (2012). Biochar's role as an alternative N-fertilizer: Ammonia capture. Plant and Soil, 350, 35-42. https://doi.org/10.1007/s11104-011-0930-8

Steiner, C., Glaser, B., Teixeira, W. G., Lehmann, J., Blum, W. E. H., \& Zech, W. (2008). Nitrogen retention and plant uptake on a highly weathered central Amazonian Ferralsol amended with compost and charcoal. Journal of Plant Nutrition and Soil Science, 171, 893-899. https://doi.org/10.1002/jpln.200625199

Tani, Y., \& Umezawa, Y. (2005). Ion-selective electrodes. Sensor Letters, 3, 99-107. https://doi.org/10.1166/ sl.2005.021

Vitousek, P. M., Cassman, K., Cleveland, C., Crews, T., Field, C. B., Grimm, N. B., \& Sprent, J., I. (2002). Towards an ecological understanding of biological nitrogen fixation. Biogeochemistry, 57, 1-45. https://doi.org/10.1023/A:1015798428743

WHO (World Health Organization). (2006). Guidelines for drinking-water quality (Vol. 1, Recommendations). World Health Organization, Geneva.

Yao, Y., Gao, B., Zhang, M., Inyang, M., \& Zimmerman, A. R. (2012). Effect of biochar amendment on sorption and leaching of nitrate, ammonium, and phosphate in a sandy soil. Chemosphere, 89, 1467-1471. https://doi.org/10.1016/j.chemosphere.2012.06.002

Zhao, X., Wang, S., \& Xing, G. (2014). Nitrification, acidification, and nitrogen leaching from subtropical cropland soils as affected by rice straw-based biochar: Laboratory incubation and column leaching studies. Journal of Soils and Sediments, 14, 471-482. https://doi.org/10.1007/s11368-013-0803-2

\section{Copyrights}

Copyright for this article is retained by the author(s), with first publication rights granted to the journal.

This is an open-access article distributed under the terms and conditions of the Creative Commons Attribution license (http://creativecommons.org/licenses/by/4.0/). 